\title{
Csapadék-árhullám reakcióidók meghatározása pécsi vízfolyások esetében
}

\section{Domján Anita ${ }^{1}$ - Ronczyk Levente ${ }^{2}$ - Nagy Gábor ${ }^{3}$ - Czigány Szabolcs ${ }^{4}$}

\author{
${ }^{1}$ technikus, Pécsi Tudományegyetem,Földrajzi Intézet, E-mail: danita@gamma.ttk.pte.hu \\ ${ }^{2}$ adjunktus, Pécsi Tudományegyetem, Térképészeti és Geoinformatikai Tanszék,E-mail: hidrogen@gamma.ttk.pte.hu \\ ${ }^{3}$ doktorandusz, Pécsi Tudományegyetem,Földtudományok Doktori Iskola,E-mail: gnagy@gamma.ttk.pte.hu \\ ${ }^{4}$ egyetemi docens, Pécsi Tudományegyetem, Természet- és Környezetföldrajzi Tanszék, \\ E-mail:sczigany@gamma.ttk.pte.hu
}

A Mecsek déli lejtöjén fekvö Pécs tagolt domborzattal és a vizzáró felszinek magas ará-
nyával jellemezhetö. A spontán és nem megfelelöen ellenörzött városfejlesztés következtében a
csatornahálózat és a csapadékvíz elvezetése nem szakszerüen megoldott a városban, ami jelen-
tös elöntéseket és károkat okoz föként nagyintenzitású csapadékokat követöen. A jelen kutatás
célja a csapadéktöbbletböl származó károkra való felkészülés elösegítése, pontosan a védeke-
zésre rendelkezésre álló idö meghatározása a Pécsi-viz részvizgyüjtöi esetében. Az összegyü-
lekezési idöket a 2014-ben öt vizmércéböl és 12 csapadékszenzorból, valamint léghömérsék-
let mérökböl, talajnedvesség-szenzorokból álló hidrometeorológiai monitoringhálózat adatai
szolgáltatták. Eredményeink alapján az árhullámok reakcióideje függvényszerü összefüggést
mutatott a csapadékesemények átlagos és maximális intenzitásával. A reakcióidö a vizsgált
események 50 százalékában kevesebb, mint egy óra volt, a legrövidebb reakcióidö esetében
pedig 5 percet regisztráltunk. Ugyan évszakos összefüggést nem sikerült megállapitani a csa-
padékintenzitás és a reakcióidök között, azonban alapvetöen a nyári és az öszi csapadékese-
mények rövidebb reakcióidövel rendelkeztek, mint a téli és tavaszi események. Eredményeink
jó alapot nyújthatnak hidrometeorológiai monitoringhálózatok tervezéséhez, valamint adatot
szolgáltathatnak a városgazdálkodási vállalat (BIOKOM Nonprofit Kft.) számára a védeke-
zési időket illetöen, valamint a csapadék-lefolyás modellek pontosabb parametrizálásához.

Kulcsszavak összegyülekezési idö, reakcióidö, csapadék-lefolyás, Pécs

DOI: 10.17799/2016.1.1

\section{Bevezetés és célkitúzés}

\subsection{A villámárvizek kialakulása}

Napjainkban az éghajlatváltozás és az antropogén hatás okozta környezeti anomáliák egyre inkább a figyelem középpontjába kerülnek (Bartholy, Bozó, \& Hapszra, 2011). Földünkön, így többek között a Kárpát-medencében is egyre gyakoribbak az ún. villámárvizek, valamint városi árvizek, amelyek a leggyakoribb természeti csapások egész Európa szerte (Stevaux \& Latrubesse, 2010; European Environment Agency [EEA], 2005; Wanielista, Kersten, \& Eaglin, 1997).

Az urbanizált területeken hirtelen megjelenő áradásokat több szerző is határozottan elkülöníti a természetes felszíneken bekövetkező áradásoktól (Georgakakos, 2006; Lóczy, Pirkhoffer, \& Gyenizse, 2012; Cobby et al., 2008). A városi árvizek gyakorisága, illetve az anyagi és emberi javakban bekövetkező kár mértéke az urbanizáció mértékével egyenes arányban nő (American Society of Civil Engineers [ASCE], 1992; Grundfest, 1977). Az intenzív csapadékok kialakulásakor olyan víztöbblet keletkezhet, amelyet sok esetben a felszíni és a felszín alatti csatornahálózat rövid idő alatt nem tud elvezetni, így hozzájárul a megnövekedett felszíni lefolyáshoz vagy árvizekhez (Hinman, 2005; Javier, Smith, Meierdiercks, Baeck, \& Miller, 2007). További probléma, hogy a városok ,életével” járó szennyező anyagok mosódhatnak be a városi vízrendszerekbe, amelyek káros hatásúak is lehetnek (Martinez, Casermeiro, Morales, Cuevas, \& Walter, 2003; Jiang \& Gan, 2012).

\subsection{Villámárvizek hazai és pécsi viszonylatban}

Ugyan Magyarország domborzatának köszönhetően nem jellemző helyszíne villámárvizek kialakulásának, 
mégis több alkalommal jegyeztek fel katasztrofális villámárvízi eseményeket hazánkban (Fábián, Görcs, Kovács, Radvánszky, \& Varga, 2009; Czigány et al., 2010). Ilyen esemény volt például 2005. április 18-án, Mátrakeresztesen, ahol a Csörgő- és a Kövicses-patakok az esőzés hatására kiléptek medrükből (Horváth, 2005). 2010. május 15-16-i esőzéseket követően Csikóstőttősön 65 embernek kellett elhagyni az otthonát, mivel a települést nyugatról határoló Hábi-csatorna nem tudta megfelelőképpen elvezetni a hirtelen megjelenő, nagy mennyiségü víztömeget.

Pécs természeti és felszínhasználati adottságai a villámárvizekkel foglalkozó szakemberek számára jó kutatási területet biztosítanak, mivel a Mecsek déli lejtőjén, és a Pécsi-víz vízgyűjtőjének felső szakaszán helyezkedik el és az impermeábilis, vízzáró rétegek aránya igen magas, helyenként a 37\%-ot is meghaladja (Ronczyk, Czigány, Horváth, \& Lóczy, 2015). Pécsett a 2010. május 15-17-i esőzések hatására jelentős helyi vízkáresemények történtek. A 60 órán át tartó csapadéktevékenység $(155 \mathrm{~mm})$ következtében a Tettye alatti területet sártenger borította el, a Magtár és a Pipacs utcákból embereket kellett kiköltöztetni. A Meszes-patak kiöntése miatt a Május 1. utca teljes szélességében hömpölygött a víz. 2014. augusztus 3-án kevesebb, mint 2 óra alatt átlagosan 75-80 mm csapadék hullott le, ami miatt a Megyeri úti szennyvízátemelőnél az esővíz túlterhelte a rendszert, aminek következtében a szennyvízzel kevert esővíz 8 méter magasan megtöltötte a gépházat.

\section{3. Összegyülekezési és reakcióidốk számítása egységárhullámok esetében}

A csapadéktöbblet a csapadéknak azon része, amely nem tározódik a felszínen vagy a talajban, hanem lefolyik a vízgyüjtőben és annak kifolyási pontján távozik (Zsuffa, 1996). Ez tulajdonképpen a közvetlen felszíni vagy felszín alatti lefolyás, ami vagy a vízfolyásokon, vagy városi területek esetében a csatornahálózaton (csapadékcsatorna) távozik a vízgyüjtőből (Ronczyk \& Czigány, 2014; Ronczyk et al., 2015). Az árhullámok levonulásának ismerete, illetve becslése megkívánja a hidrológiai ciklus részfolyamatainak ismeretét, a terület vízmérlegét és hidraulikai folyamatainak ismeretét, illetve elsősorban azt, hogy a lehulló csapadék milyen arányban fog eloszlani a tározás és a lefolyás között (Klug \& Oana, 2015).

A vízgyüjtő csapadékeseményre adott válaszát számtalan környezeti peremfeltétel szabályozza (McCuen, 2009; Green \& Nelson, 2002). Ezek közül az egyik legfontosabb az összegyülekezési idő $\left(t_{c}\right)$, amely azt jelenti, hogy mennyi idő szükséges a víznek a vízgyüjtő hidraulikai értelemben legtávolabbi pontjától ahhoz, hogy eljusson a vízgyüijtő kifolyási pontjáig (Szlávik \& Sziebert, 2006). Ez megfelel annak, amikor a vízgyüjtő teljes területe hozzájárul a lefolyáshoz (Stelczer, 2000), azaz a csapadékesemény kezdete és a tetőző vízhozam között eltelt időt értjük alatta. Gyakorlati oldalról nézve ez a védekezésre, vagy riasztásra fordítható időt jelenti.

Azösszegyülekezési idő meghatározása történhet az idő mérésével és tapasztalati (empirikus) egyenletek, modellek segítségével (Grimaldi, Petroselli, Tauro, \& Porfiri, 2012). Az empirikus egyenletek több változata is elterjedt világszerte. Giandotti egyenlete (Giandotti, 1934) széleskörủen használt Olaszországban. Az Egyesült Államokban több egyenletet is sikeresen használnak a hidrológiai szakemberek, mint például a Kirpich-egyenletet (Kirpich, 1940), az NRCS-egyenletet [National Research Conservation Sevice] (Folmar, Miller, \& Woodward, 2007), az Izzard-egyenletet (Izzard, 1946), a Federal Aviation Administration [FAA] egyenletét (ASCE, 1992), valamint Kerby egyenletét (Kerby, 1959). Ahol a felszíni lefolyás jelentősebb, mint a mederbeli lefolyás, ott jól használható Morgali \& Linsley (1965) egyenlete. Yen \& Chow (1983) az összegyülekezési idő számítása során már a csapadékintenzitás mértékét is figyelembe vette, míg mások a tározási együttható és az összegyülekezési idő arányát vették alapul az egységárhullám modellezésénél (Straub, Melching, \& Kocher, 2000).

Mivel az összegyülekezési idő közvetlenül nem mérhető, ezért időtartama úgy becsülhető, hogy a lefolyási pályákat szegregáljuk olyan egységekre, amelyek magukba foglalják a felszínen történő lefolyást, illetve az időszakos vagy állandó folyáspályákat (patak- és folyómedreket) (US Army Corps of Engineers [USACE], 2001; Aronica \& Candela, 2007). Az összegyülekezési idő azonban számos környezeti paramétertől függ, azaz vízgyüjtő specifikus érték. Ilyen paraméter pl. a csapadék intenzitása (Szlávik \& Sziebert, 2006), a felszínborítás típusa (Ronczyk et al., 2015), a kezdeti talajnedvesség (Czigány et al., 2010; Pirkhoffer, Czigány, Hegedüs, Balatonyi, \& Lóczy, 2013; Hegedüs, 2014;) vagy a vízgyüjtő formája és átlagos lejtőszöge. Városi vízgyüjtők esetében a csapadékelvezető hálózat struktúrája, vezetőképessége, valamint az impermeábilis felszínek aránya lehet a legfontosabb tényező (Ronczyk \& Wilhelm, 2006). Több szerző vélt összefüggést felfedezni a csapadékintenzitás és az összegyülekezési idő között (pl. Sarangi et al., 2007; Hegedüs et al., 2013).

Jelen kutatás alapvető célja, hogy meghatározzuk egyes pécsi vízfolyások reakcióidejét a 2014-es év csapadék és vízállás adatai alapján. Természetesen a reakcióidő nem egyezik meg a hidrológiai értelemben meghatározott öszszegyülekezési idővel, de arányos azzal. A reakcióidők számítása során azt az időtartamot definiáltuk, amely eltelt a csapadékesemények kezdete, illetve maximális intenzitása és a tetőző árhullám $\left(Q_{\max }\right.$, illetve $\left.h_{\max }\right)$ között, nyolc csapadékszenzor-vízállás mérce párosra a Pécsi-vízfolyásra és mellékvizeire. Ezek az adatok hasznos információkat nyújthatnak Pécs város városgazdálkodási vállalata, a BIOKOM Nonprofit Kft. számára, illetve a katasztrófavédelem munkatársainak is. 


\section{Eszközök és módszerek}

\subsection{A felhasznált eszközök}

Méréseinkhez a hidrometeorológiai monitoringrendszer közel 10 km²/állomás lefedettséggel rendelkező hálózati (162 km²/14 állomás) adatait használtuk fel. A csapadékesemények regisztrálását Boreas (Boreas Kft., Érd), Lambrecht (Lambrecht GmbH., Göttingen, Németország) és Decagon (Decagon Devices Inc., Pullman, Washington állam, Egyesült Államok) gyártmányú billenőedényes ECRN-100 típusú csapadékmérőkkel végeztük 10 perces időbeli felbontással.

Vízállásmérő szenzorok öt mérőhelyen kerültek kihelyezésre. A DATAQUA gyártmányú (DATAQUA Kft., Balatonalmádi) szenzorok elhelyezésnek fö szempontja az volt, hogy lehatárolható legyen az egyes részvízgyüjtők (főgyüjtők) hozzájárulása az árhullámok víztömegéhez. A vízhozamok kiszámolását $Q-h$ görbék segítségével végeztük el a Meszes-patak (Mohácsi út), Ürögi-patak (Páfrány utca) és Bálics-patak esetében. Kutatásunkhoz öt vízmérce adatait használtuk fel.

\subsection{Az összegyülekezési idő kiszámítása}

Számításaink során a fent említett monitoring hálózat méróállomásai által regisztrált adatokat használtuk fel nyolc csapadékmérö-vízmérce pár esetében (1. ábra). Minden esetben a vízmércéhez tartozó, ugyanazon vízgyüjtő magasabb részén elhelyezkedő csapadékszenzor adatait vettük figyelembe. A jelen kutatáshoz a Rezgő utcai, a Meszesi, az Erdész utcai és a Szentkúti csapadékszenzorok 2014-es adatait használtuk fel, ezek mindegyike automata, billenőedényes szenzor.

$\mathrm{Az}$ összegyülekezési idő értékét kétféleképpen határoztuk meg: (a) a csapadékesemény kezdete és az árhullám tetőzése között eltelt idő $\left(t_{p i}\right)$, valamint $(b)$ a csapadékintenzitás maximuma és az árhullám tetőzése között eltelt idő $\left(t_{p m}\right)$. Három esetben egy vízállásmérő szenzorhoz több csapadékmérő adatait rendeltük a nagyobb térbeli lefedettség és az árhullám terjedésére irányuló pontosabb számítások érdekében, valamint figyelembe vettük a vízgyüjtő domborzati adottságait is a nyolc csapadékszenzor-vízmérce pár kiválasztásakor (1. táblázat és 1. ábra).

A Boreas gyártmányú csapadékszenzorok nem csak a
10 perces csapadékösszegek mérésére alkalmasak, hanem regisztrálják az események maximális intenzitását is a 10 perces mérési időintervallumon belül. Ezek az intenzitás értékek értelemszerủen magasabbak az átlagos csapadékintenzitás értékeknél. Az események vizsgálata során külön elemeztük ezekhez az intenzitásértékekhez tartozó reakcióidőket. A teljes csapadékesemény maximális intenzitásától a vízállás tetőzéséig eltelt idők $\left(t_{p m}\right)$ között az esetek nagy részében nem figyeltünk meg olyan szoros összefüggést, mint a $t_{p i}$ esetében.

A maximális intenzitás és a $h_{\max }$ közötti összefüggés vizsgálatára összesen hét vízmérce-csapadékszenzor párost elemeztünk. Az Erdész utcai csapadékszenzor (Decagon ECRN-100) nem regisztrál maximális intenzitás adatokat, így a Bálics-patak esetében a $t_{p m}$-re vonatkozóan nem tudtunk számításokat végezni. A $t_{p m}$ idők elemzése során ugyanazon eseményeket vizsgáltuk, mint a $t_{p i}$ idők meghatározásához.

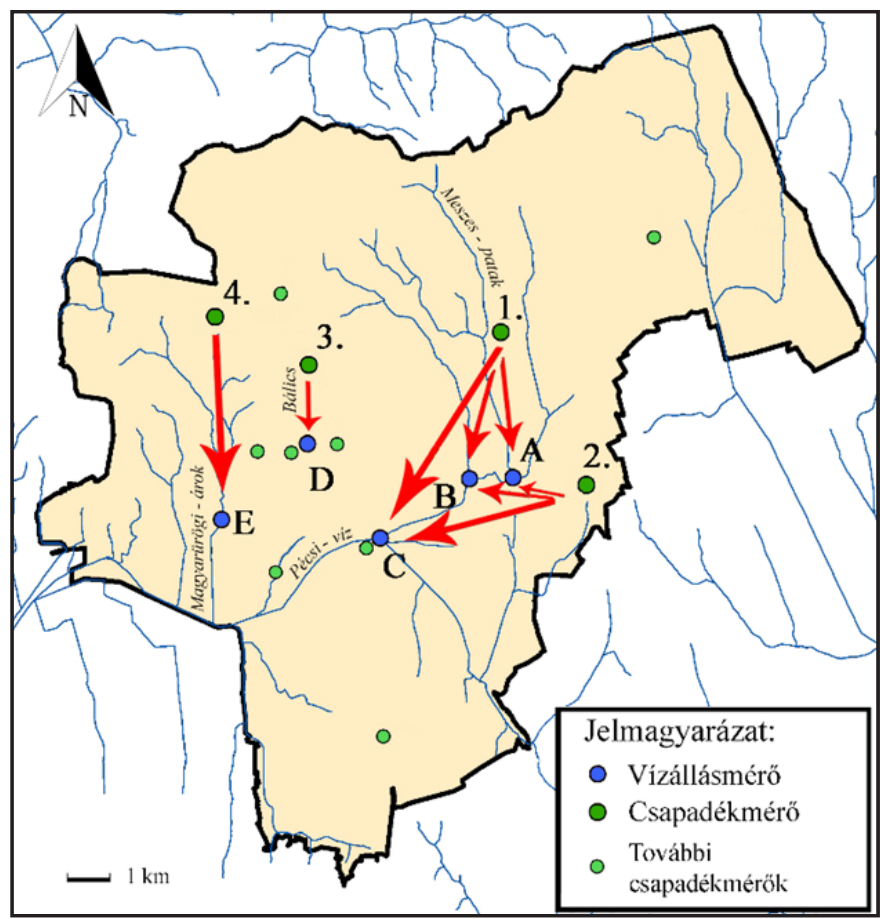

1. ábra: A vízgyứjtô-specifikus reakcióidők számolásához használt csapadékszenzor és vízmérce párok Pécsett. (1.) Meszes; (2.) Rezgő utca; (3.) Erdész utca; (4.) Szentkút (A) Mohácsi út; (B) Tüskésrét; (C) Bőrgyár; (D) Bálics; (E) Ürögi - Páfrány utca

1. táblázat: A magasságmodellek különbségeinek aránya.

\begin{tabular}{ccccc}
\hline Csapadékszenzor & Csapadékszenzor típusa & Vízmérce & Vizsgált események száma (db) & Párosítás kódja \\
\hline Meszes & Boreas & Mohácsi út & 21 & M1 \\
Meszes & Boreas & Tüskésrét & 29 & T1 \\
Meszes & Boreas & Börgyár & 14 & $\mathrm{~B} 1$ \\
Rezgő utca & Boreas & Mohácsi út & 28 & $\mathrm{M} 2$ \\
Rezgő utca & Boreas & Tüskésrét & 29 & $\mathrm{~T} 2$ \\
Rezgö utca & Boreas & Börgyár & 11 & $\mathrm{~B} 2$ \\
Szentkút & Boreas & Ürög (Páfrány u.) & 18 & Ü1 \\
Erdész utca & Decagon ECRN-100 & Bálics & Bá1 \\
\hline
\end{tabular}




\section{Eredmények}

Pécs átlagos évi csapadékösszege a 2014-es évben területi átlagban elérte a $988 \mathrm{~mm}-\mathrm{t}$ (minimum: $955,9 \mathrm{~mm}$ - Rezgő utca; maximum: 1027,4 mm - Damjanich gépház). A legnagyobb intenzitásokat, a sokévi éghajlati mintázatnak megfelelően a nyári hónapokban regisztráltuk (2. ábra). A vízállás idősorokban jelentős adathiánynyal szembesültünk (2.ábra), de méróállomásonként így is 11-34 csapadékesemény-árhullám kapcsolatot tudtunk vizsgálni.

\subsection{A csapadék kezdetétól a vízállás tetôzéséig eltelt idó az átlagos csapadékintenzitás függvényében $\left(t_{p i}\right)$ a pécsi vízfolyásokon}

Az átlagos intenzitás és a vízállás tetőzése között eltelt időket $\left(t_{p i}\right)$ elsőként a Meszes patakon elhelyezett Mohácsi úti vízmérce adatai, illetve két csapadékmérő állomás adatai alapján vizsgáltuk (3. ábra). Erősebb korrelációt a Rezgő utcai szenzor által regisztrált adatokkal tapasztaltunk (M2), ebben a hozzárendelésben a korrelációs koefficiens értéke elérte a $r^{2}=0,6479$-et, míg a meszesi állomás adataival való kapcsolat (M1) kissé ez alatt maradt, a korrelációs együttható $r^{2}=0,602$ volt. Mindkét esetben az adatokra illesztett trendvonal egyenlete hatvány összefüggést mutatott. Az „M2” jelü össze- hasonlítás során az összes esetek (19) mindössze 26,3\%a rendelkezett 60 percnél rövidebb reakcióidővel. Az összes kiválasztott esemény alapján elmondható, hogy az 1,6 mm/10 perc intenzitást meghaladó események maximum 130 percen belül megjelentek a vízállásban. A $t_{p i}$ idők 30 és 430 perc között, az átlagos intenzitások pedig 0,3 és $5,6 \mathrm{~mm} / 10$ perc között változtak.

A Pécsi-vízen két helyen is rendelkezünk vízállásmérő szenzorral. A keletebbre eső adatgyüjtő állomás Tüskésréten került telepítésre 2013-ban. Ennek a vízmércének az adatait is a fent említett két csapadékszenzor adataival hasonlítottuk össze, és hasonlóképpen a Rezgő úti csapadékmérő adataival való korreláció bizonyult erősebbnek (T2), ebben a párosításban a korrelációs koefficiens értéke $r^{2}=0,5844$ volt. A meszesi állomás adataival való öszszehasonlítás esetén (T1) is jónak nevezhető korrelációt tapasztaltunk, $r^{2}=0,5572$. Ennek megfelelően az adatokra illesztett trendvonal egyenlete itt is mindkét esetben hatvány összefüggést mutatott. A „T2” jelzésű párosítás esetén (28 esemény), az esetek 28,6\%-ában a csapadék kezdetét követően maximum 60 percen belül megjelent az árhullám. A 2 mm/10 perc intenzitást meghaladó események kivétel nélkül, legfeljebb 70 percen belül a vízállás tetőzését jelentették. A vizsgált események során a $t_{p i}$ idők 10 és 590 perc között, az átlagos intenzitások pedig 0,1 és $4,3 \mathrm{~mm} / 10$ perc között változtak.
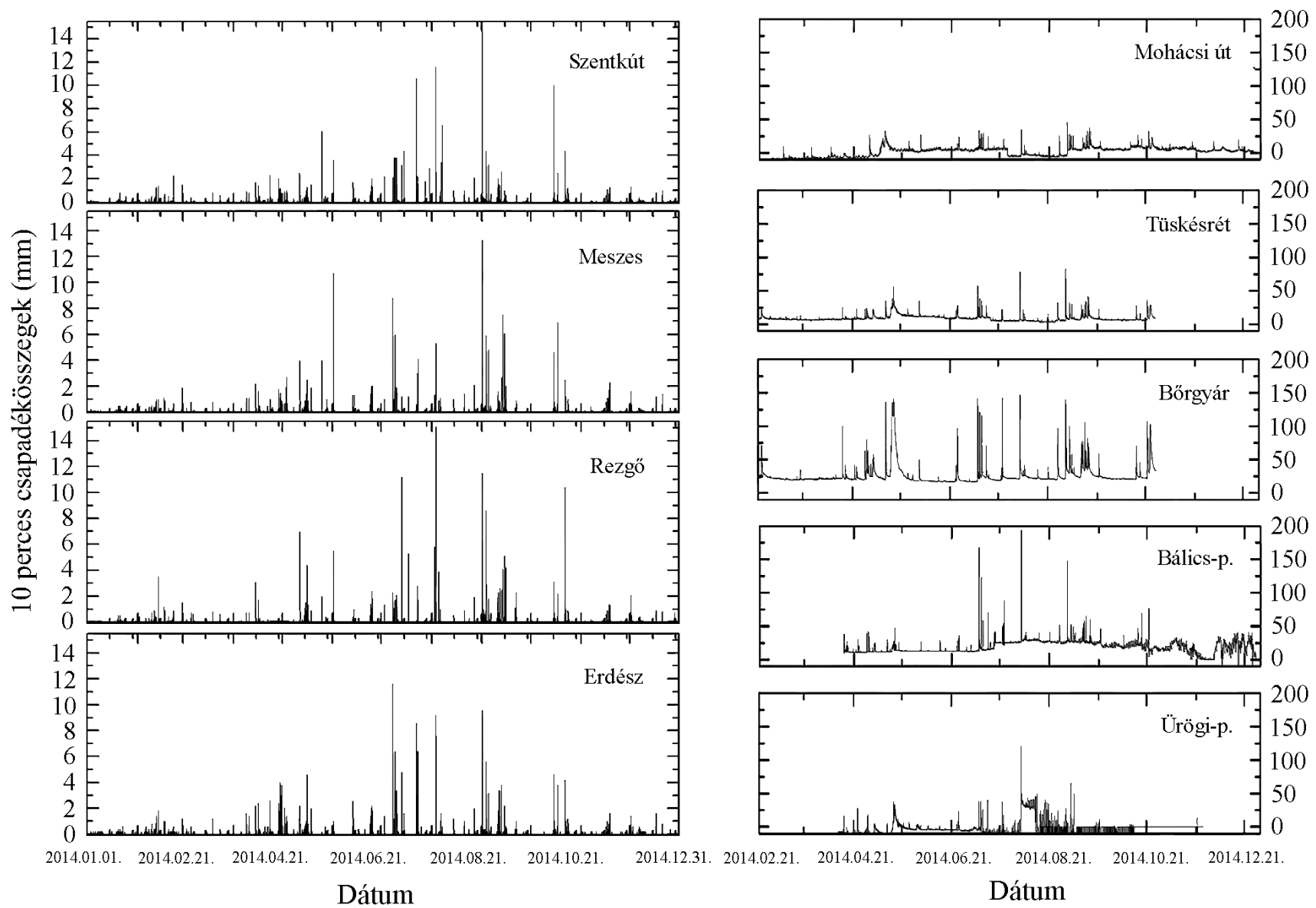

Dátum

Dátum

2. ábra: 10 perces csapadékösszegek a 2014-es évben a pécsi hidrometeorológiai méróhálózat négy mérőpontján (balra). Vízállás idósorok a 2014-es évre a pécsi hidrometeorológiai méróhálózat öt mérőpontján (jobbra). 


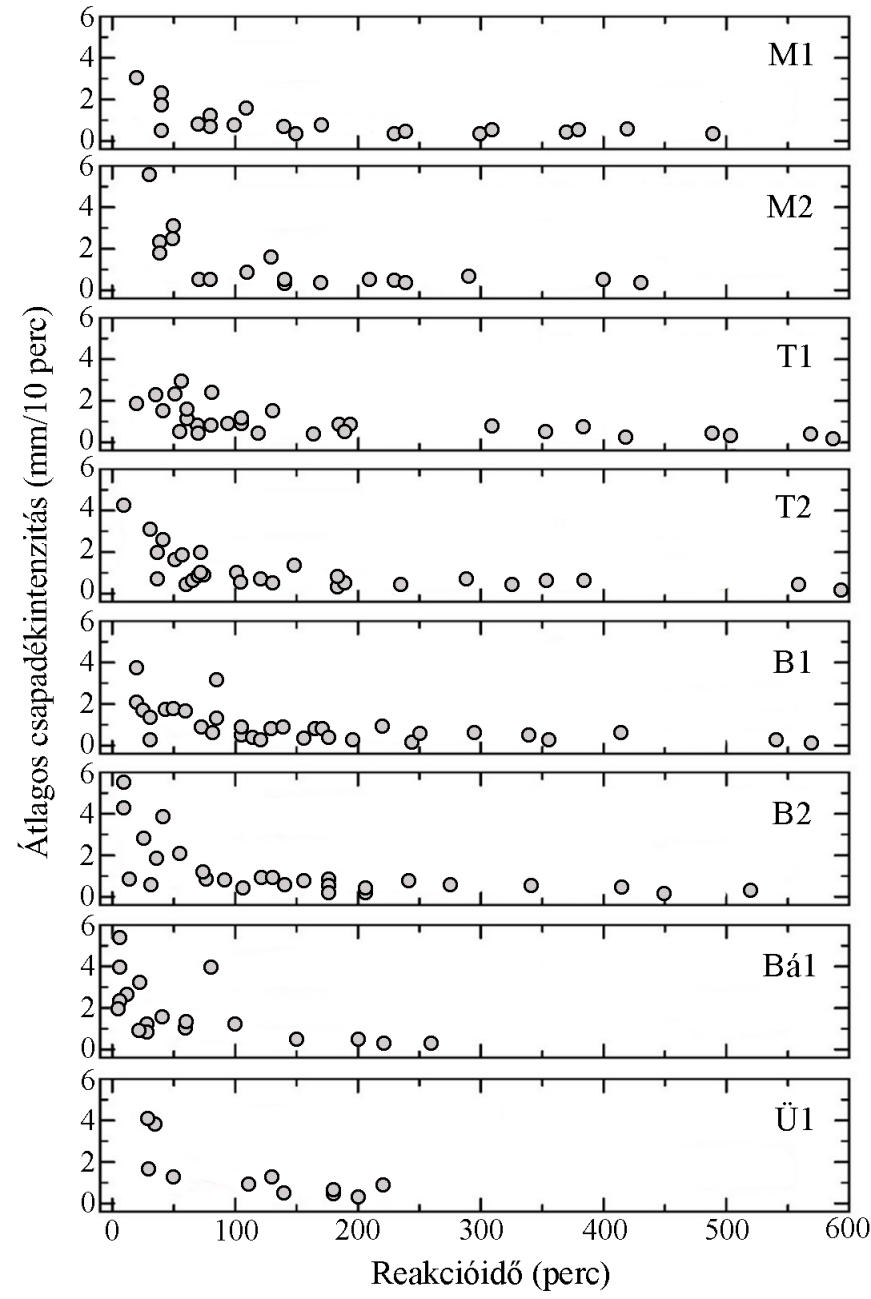

3. ábra: Az átlagos csapadékintenzitás $\left(t_{p i}\right)$ és a tetôző árhullám $\left(h_{\max }\right)$ közötti idóbeni összefüggés a 2014-es évben.

A Pécsi-vízen telepített nyugatabbra eső vízmérce a korábbi Bőrgyárnál található. Ennek a szenzornak az adatait is a meszesi (B1), illetve a Rezgő utcai (B2) csapadékmérö adataival hasonlítottuk össze és ismételten a Rezgő utcai adatokkal figyeltünk meg szorosabb összefüggést. A „B2” párosítás esetén a korreláció $r^{2}=0,5918$, míg a „B1” párosításban $r^{2}=0,5583$ volt. A korábbiakkal megegyezően az adatokra illesztett trendvonal ismét hatvány összefüggést mutatott. A „B2” párosításban 29 eseményt vizsgáltunk. Ezen esetek 27,6 \%-ában a csapadék kezdetét követően maximum 60 percen belül megjelent az árhullám. Kivétel nélkül minden esetben elmondható volt, hogy az 1,2 $\mathrm{mm} / 10$ perc intenzitást meghaladó események maximum 73 percen belül a vízállás tetőzését jelentették. A $t_{p i}$ idök 10 és 520 perc között változtak.

Tizennyolc eseményt vizsgáltunk a Bálics-patakon elhelyezett vízmérce és az Erdész utcai csapadékszenzor viszonyában (Bá1). Az esetek 72,2\%-ában a csapadék kezdetét követően 1 órán belül megjelent az árhullám. Ez a magas arány magyarázható az egymáshoz rendelt szenzorok közötti kis távolsággal, a meredek domborzattal és a betonfelszínek magas arányával. Egy kivétellel elmondható volt, hogy a $1,5 \mathrm{~mm} / 10$ percet meghaladó intenzitású események 40 percen belül megjelentek a vízál- lásban. A vizsgált események reakcióideje 5 és 260 perc között változott. A legnagyobb átlagos intenzitás mértéke $5,5 \mathrm{~mm} / 10$ perc volt, melyhez mindössze 5 perces reakcióidő társult. A legkisebb átlagos intenzitású esemény $0,3 \mathrm{~mm} / 10$ perc intenzitással rendelkezett, ami csak 260 perccel a csapadék kezdetét követően váltott ki tetőzést a vízállásban. Az átlagos intenzitás és a reakcióidő között szoros összefüggés figyelhető meg, ebben az esetben a korreláció erősnek mondható, $r^{2}=0,6752$. Az adatokra illesztett trendvonal egyenlete exponenciális összefüggést mutatott. A vizsgált események között mindössze egy olyan akadt, amelynek intenzitása nem indokolta a hosszú reakcióidőt, így ennek okát a csapadék intenzitásának változásában, illetve a talajnedvesség befolyásoló hatásában kerestük. Ez az esemény az augusztus 3-i zivatar volt, amikor átlagosan 3,9 mm csapadék hullott le 10 perc alatt (bár voltak jóval intenzívebb időszakok is), viszont ez a mennyiség a vízállásban csak 80 perc múlva jelentkezett. Ez különösen meglepő a csapadékesemény rendkívül intenzív és konvektív jellegéből fakadóan. Az esemény kezdetét követően (12:30) a vízállás fokozatosan növekedett egészen 13:30-ig. A talajnedvesség-tartalom az esemény kezdetekor mindössze $0,1 \mathrm{~m}^{3} \mathrm{~m}^{-3}$ volt, így lassú ütemben, de el tudta vezetni a többlet csapadék egy részét. 13:30-at követően a talajnedvesség-tartalom gyorsan növekedett, ezzel egy időben a vízállás növekedése is gyorsuló tendenciát mutatott. A tetőzés időpontjában (13:50) a talajnedvesség-tartalom már elérte a maximális értékét, a talaj több csapadékot nem tudott befogadni.

Az Ürögi-patakon (Uránvárosi buszvégállomás) elhelyezett vízmérce adatait a szentkúti csapadékszenzor adataival összevetve (Ü1) tizenegy eseményt vizsgáltunk. A kiválasztott események 45,5\%-ában a csapadék kezdetét követően 60 percen belül megjelent az árhullám. Egy kivétellel a $0,9 \mathrm{~mm} / 10$ perc intenzitást meghaladó események maximum 110 percen belül tetőztek a vízállásban. A feldolgozott események reakcióideje 30 és 220 perc között változott. A legnagyobb átlagos intenzitású esemény $4,1 \mathrm{~mm} / 10$ perc intenzitással rendelkezett, mely mindössze 30 perccel a csapadékesemény kezdetét követően a vízállás tetőzését okozta. Az átlagos intenzitás és a reakcióidő között kifejezetten szoros, hatványos összefüggést tapasztaltunk $\left(r^{2}=0,7412\right)$. Ennek a párosításnak az esetében két olyan esemény volt, melynek intenzitása nem indokolta a hozzá tartozó reakcióidőt. Ilyen eset volt például a július 9-i csapadékesemény, melynek az átlagos intenzitása $1,6 \mathrm{~mm} / 10$ perc volt, ami az adatokra illesztett trendvonal alapján 55 perces $\left(1,6=70,761 \mathrm{x}^{-0,949}\right)$ reakcióidőt jelentene, mégis a csapadék kezdetét követően már 30 perc múlva megjelent a vízállásban. Ez a kivételesen gyors reakcióidő azzal magyarázható, hogy az esemény során az intenzitás tágabb határok között mozgott, 13:10kor és 13:20-kor az átlagos intenzitás mértékének több mint kétszerese hullott. 


\subsection{A teljes csapadékesemény maximális intenzitásától a vízállás tetőzéséig eltelt reakcióidôk $\left(t_{p m}\right)$ a pécsi vízfolyásokon}

A Mohácsi úti vízmérce adatait a meszesi (M1) és Rezgő utcai (M2) csapadékmérő adataival összevetve, a csapadékesemények maximális intenzitásától a vízállás tetőzéséig eltelt időket vizsgálva szorosabb kapcsolatot figyeltünk meg a meszesi adatokkal $\left(r^{2}=0,641\right)$. A Rezgő utcai adatokkal való összehasonlítás esetén (M2) a korrelációs együttható $r^{2}=0,5704$ volt. A $t_{p i}$-hez hasonlóan ebben az esetben is hatvány összefüggést mutattunk ki az adatok között. Ebben a párosításban (M1) a vizsgált események 52,4\%-ában a maximális intenzitást követően legfeljebb 1 órán belül megjelent az árhullám. A $t_{p m}$ idők 5 és 370 perc között változtak (4. ábra). A leválogatott események között a legnagyobb regisztrált maximális intenzitás $300 \mathrm{~mm} / \mathrm{h}$, míg a legkisebb $11 \mathrm{~mm} / \mathrm{h}$ volt.

A tüskésréti vízmérce esetében a $t_{p m}$ idők a $t_{p i}$ időkkel egyetemben a Rezgő utcai szenzorral (T2) mutattak kifejezetten erős korrelációt $\left(r^{2}=0,7917\right)$, igaz ebben az esetben exponenciális összefüggést figyeltünk meg. A meszesi adatokkal való kapcsolat (T1) jóval szerényebbnek bizonyult $\left(r^{2}=0,5297\right)$, valamint hatványos összefüggést mutatott. A Rezgő utcai adatok alapján elmondható,

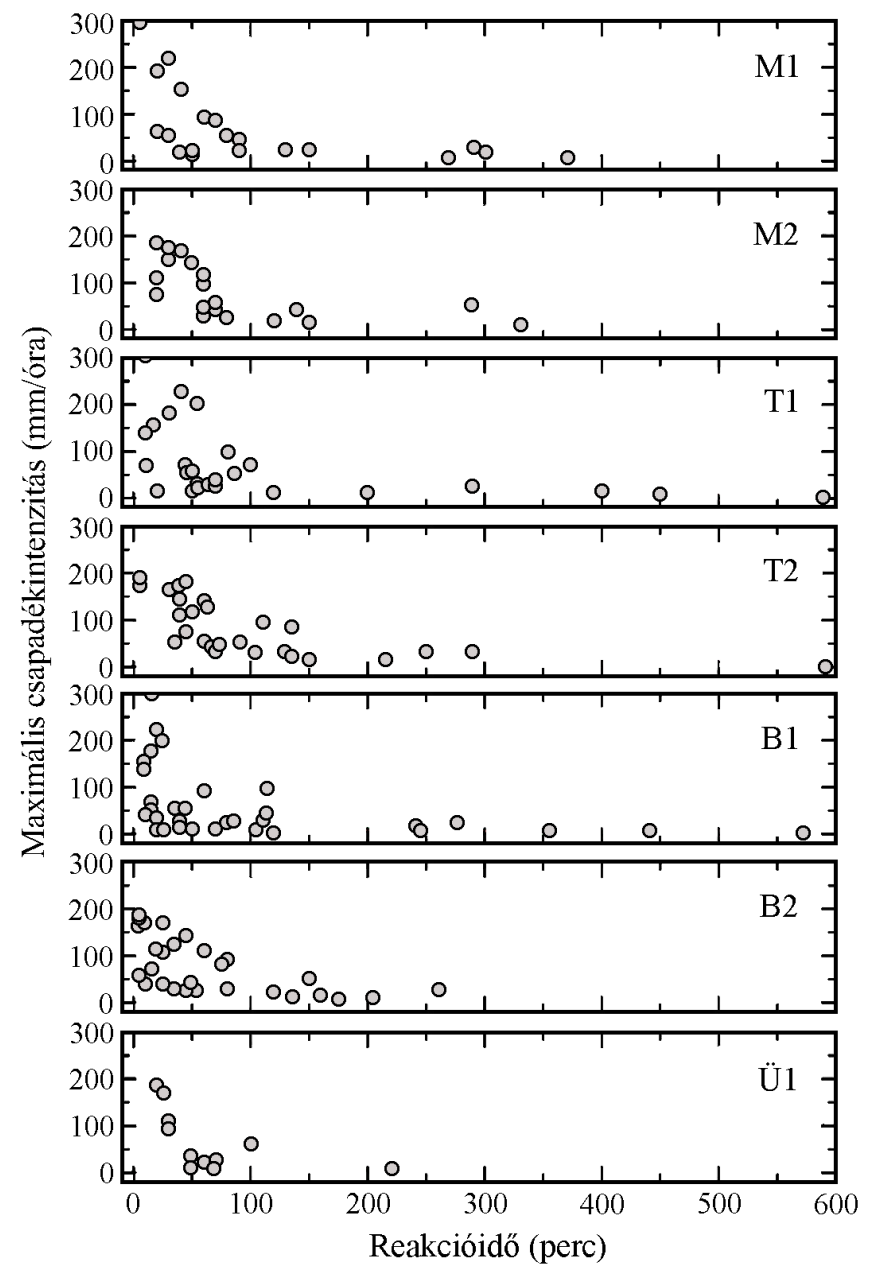

4. ábra: A maximális csapadékintenzitás $\left(t_{p m}\right)$ és a tetôző árhullám $\left(h_{\max }\right)$ közötti idóbeni összefüggés a 2014-ben. hogy a vizsgált események 42,9 \%-ában a maximális intenzitást követően legfeljebb 60 percen belül megfigyelhető volt a vízállás tetőzése (ez az arány a $t_{p i}$ esetében $28,6 \%$ volt). A $t_{p m}$ idők 5 és 590 perc között, míg a maximális intenzitások 0,1 és 189,4 mm/h között változtak. Kivétel nélkül elmondható volt, hogy a $80 \mathrm{~mm} / \mathrm{h}$ maximális intenzitást meghaladó események 135 percen belül a vízállás tetőzését okozták.

A Börgyárnál található vízmérce adatainak elemzése során ismét a Rezgő utcai csapadékszenzor adataival találtunk szorosabb összefüggést $\left(r^{2}=0,5168\right)$, ebben az esetben is exponenciális kapcsolatot figyeltünk meg. A „B1” korreláció némileg elmaradt ettől az értéktől $\left(r^{2}=0,5053\right)$, illetve az adatok között hatványos összefüggés mutatkozott. A „B2” párosítás esetén a vizsgált események $62,1 \%$-ában a maximális intenzitást követően 60 percen belül megjelent az árhullám (ez az arány a $t_{p i}$ esetében $27,6 \%$ volt). A $t_{p m}$ idök 5 és 260 perc között változtak. A vizsgált események során a maximális intenzitás határértékei 6,1 és $189,4 \mathrm{~mm} / \mathrm{h}$ voltak.

Az Ürögi-patakon (Uránvárosi buszvégállomás) elhelyezett vízmérce és a Szentkút csapadékszenzor (Ü1) adatainak elemzése során megfigyeltük, hogy az események 63,6\%-ában a csapadék maximális intenzitását követően legfeljebb 60 percen belül a lehullott csapadék a vízállás tetőzésében mutatkozott meg (ez az arány a $t_{p i}$ esetében 45,5\% volt). A $t_{p m}$ idők 20 és 220 perc között, a maximális intenzitások pedig 6,4 és $180 \mathrm{~mm} / \mathrm{h}$ között változtak. Az illesztett trendvonal alapján az adatok közötti korreláció szoros, de elmarad a $t$ korrelációtól, ez esetben $r^{2}=0,6343$ ( $t_{p i}$ esetén $\left.r^{2}=0,7412\right)$. A $t_{p i}$-hez hasonlóan ismét hatványos összefüggés volt megállapítható az adatok között.

\section{Következtetések}

Pécs tagolt domborzati adottságainak, a burkolt felszínek magas arányának valamint, a vízgyüjtők kis méretének megfelelően az összegyülekezési idők minden csapadékmérő-vízmérce párosra nagyon rövidek voltak, legtöbb esetben 3 óránál rövidebb idő alatt megjelent az árhullám a vízmércénél a csapadék kezdetét követően. Mind a $t_{p m}$, mind a $t_{p i}$ esetében, a korábbi eredményeknek megfelelöen (Hegedüs, 2014) a csapadékintenzitás és a reakcióidő között szignifikáns összefüggést, de fordított arányosságot figyeltünk meg. Azonban kiemelendő, hogy egy adott vízmércén átfolyó víztömeghez olyan részvízgyưjtők is dominánsan hozzájárulhatnak, amelyeken nincsenek mért csapadékadatok (pl. Tettye és Belváros), így a megfigyelt árhullám eredete nem biztos, hogy teljes egészében a feltételezett csapadékszenzorhoz köthetö. Ilyen módon gyakorlatilag csak a legközelebbi vízmércéket lehet figyelembe venni, illetve a csapadékeseményeket egyszerre több szenzoron térben kell vizsgálni. Ebből fakadhat az, hogy például a „B2” nem csak a saját kapcsolatát 
2. táblázat: Jellemző reakcióidók $t_{p i}$ és $t_{p m}$ idók esetén a vizsgált csapadékszenzor-vízmérce párosokra.

\begin{tabular}{|c|c|c|c|c|c|c|}
\hline $\begin{array}{c}\text { Csapadékszenzor- } \\
\text { vízmérce }\end{array}$ & $t_{p i}($ perc) & $t_{p i}$ átlag (perc) & $t_{p i}$ szórás & $t_{p m}($ perc $)$ & $t_{p m}$ átlag (perc) & $t_{p m}$ szórás \\
\hline M1 & $20-490$ & 182 & 144 & $5-370$ & 104 & 109 \\
\hline M2 & $30-430$ & 159 & 118 & $20-330$ & 89 & 87 \\
\hline $\mathrm{T} 1$ & $20-590$ & 193 & 177 & $10-590$ & 108 & 144 \\
\hline $\mathrm{T} 2$ & $10-590$ & 163 & 155 & $5-590$ & 107 & 117 \\
\hline B1 & $20-570$ & 193 & 170 & $10-570$ & 103 & 133 \\
\hline B2 & $10-520$ & 157 & 134 & $5-260$ & 72 & 70 \\
\hline Bá1 & $5-260$ & 72 & 81 & - & - & - \\
\hline Ü1 & $30-220$ & 119 & 72 & $20-220$ & 66 & 56 \\
\hline
\end{tabular}

3. táblázat: Reakcióidók meghatározásának egyenletei $t_{p i}$ és $t_{p m}$ idók esetén a vizsgált csapadékszenzor-vízmérce párosokra, valamint a csapadékintenzitás és a reakcióidók közötti korreláció.

(A hatvány vagy exponenciális összefüggés közül a magasabb értéket vettük figyelembe, ezeket a félkövér számok jelzik.)

\begin{tabular}{|c|c|c|c|c|}
\hline $\begin{array}{c}\text { Csapadékszenzor- } \\
\text { vízmérce }\end{array}$ & $t_{p i}$ egyenlete $(y=\ldots)$ & $t_{p i}$ korreláció $\left(r^{2}=\ldots\right)$ & $t_{p m}$ egyenlete $(y=\ldots)$ & $t_{p m}$ korreláció $\left(r^{2}=\ldots\right)$ \\
\hline $\mathrm{M} 1$ & $12,134 \mathrm{x}^{-0,571}$ & 0,602 & $991,01 \mathrm{x}^{-0,737}$ & 0,641 \\
\hline M2 & $49,336 x^{-0,858}$ & 0,6479 & $1991,4 x^{-0,86}$ & 0,5704 \\
\hline $\mathrm{T} 1$ & $17,636 x^{-0,673}$ & 0,5572 & $1364,9 x^{-0,88}$ & 0,5297 \\
\hline $\mathrm{T} 2$ & $15,031 x^{-0,629}$ & 0,5844 & $154,38 \mathrm{e}^{-0,011 \mathrm{x}}$ & 0,7917 \\
\hline B1 & $19,639 \mathrm{x}^{-0,723}$ & 0,5583 & $1010,5 x^{-0,901}$ & 0,5053 \\
\hline B2 & $13,819 x^{-0,604}$ & 0,5918 & $103,74 \mathrm{e}^{-0,011 x}$ & 0,5168 \\
\hline Bá1* & $2,5293 \mathrm{e}^{-0,009 \mathrm{x}}$ & 0,6752 & - & - \\
\hline Ü1 & $70,761^{\mathrm{x}-0,949}$ & 0,7412 & $8645,6 x^{-1,375}$ & 0,6343 \\
\hline
\end{tabular}

méri, hanem valószínúleg a belvárosi felszínek gyorsabban megjelenő lefolyását is. Ezt látszik alátámasztani az a tény is, hogy kutatásaink során a vízállásokban megjelenő árhullámok száma, illetve a vízállás növekedésének mértéke a város keleti felétöl nyugat (avagy a Belváros) felé haladva egyértelmüen nőtt.

Eredményeink alapján megállapítható, hogy hidrológiai és lefolyási szempontból minden csapadékszenzor-vízmérce páros (kvázi vízgyüjtő) egyedien viselkedik. Megjegyzendő azonban, hogy a csapadékmérők és a vízszintmérők a vízfolyások más-más szakaszán helyezkednek el, így a kalkulált reakcióidőket az egyes vízfolyásokon relatív módon kell értékelni. Nem döntően, de némely esetben befolyásolta a lefolyás-beszivárgás arányát a csapadékesemény kezdetekor illetve az esemény folyamán a talajnedvesség-tartalom (pl. 2014. augusztus 3.). A feldolgozott események során az esetek túlnyomó részében a talajnedvesség nem játszott jelentős szerepet az árhullámok megjelenésében, mely eredmény ellentmond pl. Corradini, Melone, \& Smith, (1997); Cosh, Jackson, Bindlish, \& Pruegger, (2004); Collier, (2007); Gaume et al., (2009); Hegedüs, Czigány, Pirkhoffer, Balatonyi, \& Hickey, (2015) eredményeinek, akik jelentős hatást tulajdonítottak vizsgálataik alapján a talajnedvességnek. Castillo, Gómez-Plaza, \& Martínez-Mena, (2003) például jó korrelációt figyelt meg a kezdeti talajnedvesség és a beszivárgás aránya között durvább textúrájú talajok esetében.

A vizsgált csapadékszenzor-vízmérce párosok esetében a reakcióidők 5 és 590 perc között változtak a $t_{p m}$ és a $t_{p i}$ értékeit tekintve is (2. táblázat). A legrövidebb reakcióidőket a legmeredekebb és legkisebb vízgyüjtö, a Bálicsi-vízmérce feletti vízgyüjtő esetében tapasztaltuk. Itt a burkolt felületek magas aránya és a meredek domborzat járul hozzá a gyors lefolyáshoz.

A legnagyobb térbeli távolság a „B1” jelü hozzárendelés között volt $(7 \mathrm{~km})$, itt a $t_{p m}$ és a $t_{p i}$ is elérte az 570 percet. A leghosszabb reakcióidőket azonban a Meszes és a Tüskésrét közötti mércék adataiból állapítottuk meg, itt a maximális érték elérte az 590 percet is.

A korábbi irodalmi eredményekhez hasonlóan (pl. Hegedüs, 2014) a vizsgált vízgyüjtőkön is viszonylag szoros összefüggést találtunk a csapadékintenzitás és az összegyülekezési idők között (3. táblázat). A korrelációs koefficiens értéke $r^{2}=0,5572$ és $r^{2}=0,7412$ között változott a $t_{p i}$, és $r^{2}=0,5053$ és $r^{2}=0,7917$ között a $t_{p m}$ esetében. Ezek a korrelációk statisztikai alapon, hidrológiai és hidrodinamikai szemszögből tekintve már erős kapcsolatnak nevezhetők. A legjobb korrelációt általában a hatvány összefüggések hozták összesítésben, azaz együttesen tekintve a $t_{p i}$-re és a $t_{p m}$-re (3. táblázat). Azonban a $t_{p i}$ esetében nyolc esetből egyszer, míg a $t_{p m}$ esetében nyolc esetből kétszer az exponenciális összefüggés korrelációs hányadosa magasabb volt, mint a hatvány összefüggésé. A megállapított korrelációs egyenletek alapján, a csapadékintenzitás adatok függvényében becsülhetö lesz a reakcióidő, azaz a védekezésre és megelőzésre fordítható idő, mely fontos lehet nemcsak a BIOKOM Nonprofit $\mathrm{Kft}$., hanem a lakossági tájékoztatás, illetve a városvezetés, valamint a katasztrófavédelem számára is. Összes- 


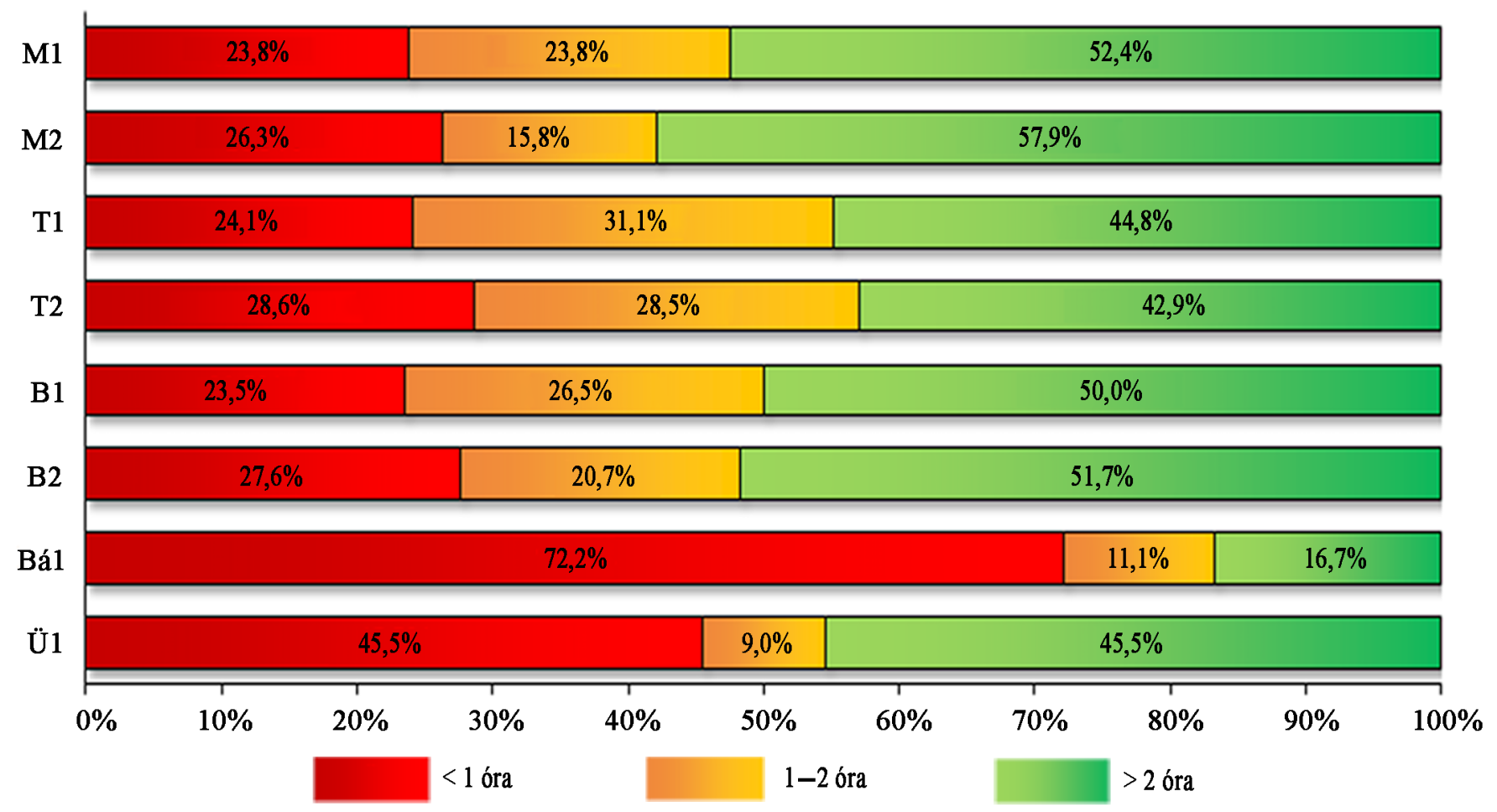

5. ábra: Reakcióidók a csapadékesemény kezdetétôl a vízállás tetôzéséig $\left(t_{p i}\right)$ a vizsgált csapadékszenzor-vízmérce párosítások esetén.

\begin{tabular}{|c|c|c|c|c|c|c|c|c|c|c|}
\hline M1 & \multicolumn{5}{|c|}{$52,4 \%$} & $19,0 \%$ & & \multicolumn{3}{|c|}{$28,6 \%$} \\
\hline M2 & \multicolumn{5}{|c|}{$57,9 \%$} & \multicolumn{3}{|c|}{$21,0 \%$} & \multicolumn{2}{|l|}{$21,1 \%$} \\
\hline $\mathrm{T} 1$ & \multicolumn{5}{|c|}{$58,6 \%$} & \multicolumn{3}{|c|}{$24,2 \%$} & \multicolumn{2}{|c|}{$17,2 \%$} \\
\hline T2 & \multicolumn{4}{|c|}{$42,9 \%$} & \multicolumn{2}{|c|}{$28,6 \%$} & & \multicolumn{3}{|c|}{$28,5 \%$} \\
\hline B1 & \multicolumn{4}{|c|}{$55,9 \%$} & & \multicolumn{3}{|c|}{$26,5 \%$} & \multicolumn{2}{|c|}{$17,6 \%$} \\
\hline B2 & \multicolumn{4}{|c|}{$62,1 \%$} & & \multicolumn{2}{|r|}{$13,8 \%$} & \multicolumn{3}{|c|}{$24,1 \%$} \\
\hline Ü1 & \multicolumn{4}{|c|}{$63,6 \%$} & & & \multicolumn{2}{|c|}{$27,3 \%$} & \multicolumn{2}{|r|}{$9,1 \%$} \\
\hline & \multirow[t]{2}{*}{$10 \%$} & $20 \%$ & $30 \%$ & $40 \%$ & $50 \%$ & $60 \%$ & $70 \%$ & $80 \%$ & $90 \%$ & $100 \%$ \\
\hline & & & 1 óra & & \multicolumn{2}{|c|}{$1-2$ óra } & \multicolumn{2}{|c|}{$>2$ óra } & & \\
\hline
\end{tabular}

6. ábra: Reakcióidók a csapadékesemény maximális intenzitásától a vízállás tetôzéséig $\left(t_{p i}\right)$ a vizsgált csapadékszenzor-vízmérce párosítások esetén.

ségében elmondhatjuk, hogy az intenzitás adatok fontos információkkal szolgálnak az esetleges árhullámok tetőzésének idejét illetően. Minden vizsgált vízmérce- csapadékszenzor hozzárendelés esetén szoros korreláció volt megfigyelhetö, az adatokra illesztett trendvonalak egyenleteinek alapján a reakcióidők jó közelítéssel becsülhetők, folyamatos adatgyüjtéssel naprakész, vízgyüjtő specifikus egyenletek állithatók fel. Így a fentiek tükrében a csapadék kezdő időpontját, illetve intenzitását online figyelve becsülhető az árhullám tetőzésének várható időpontja.

Kutatásunk legfontosabb eredménye, a csapadékintenzitás-reakcióidő korreláció kiszámítása mellett, a reakcióidők eloszlásának meghatározása a vizsgált csapadékszenzor-vízmérce párokra. Az időbeli eloszlások szemléltetésére három időbeli kategóriát határoztunk meg, kevesebb mint 1 óra, 1-2 óra és a több mint 2 óra időegységekre. 
Az 1 óránál rövidebb reakcióidők legmagasabb arányát $t_{p i}$ esetében a Bálicsi-vízmérce feletti vízgyüjtőn tapasztaltuk (72,2\%), míg a legkisebbet a „B1” kapcsolatra találtuk (5. ábra). A „Bá1” és az „Ü1” párok kivételével 1 óránál rövidebb $t_{p i}$ reakcióidők a vizsgált események mintegy negyedében fordultak elő. A 2 óránál hoszszabb események legmagasabb aránya $(57,9 \%)$ az „M2” kapcsolatra jelent meg, míg legalacsonyabb értéke a Bálics-patak vízgyüjtőjén volt.

Ugyanezeket a paraméterek a $t_{p m}$-re nézve azt tapasztaltuk, hogy az 1 óránál rövidebb reakcióidők legmagasabb arányban az „Ü1” páros esetében voltak jelen (itt nem volt „Bál” összehasonlítás). Ugyanakkor ebben a korrelációban volt a legkisebb a 2 óránál hosszabb reakcióidők aránya is. Nem elhanyagolható tény, hogy a „T2" páros kivételével minden hozzárendelés esetén az 1 óránál rövidebb $t_{p m}$ idők több mint $50 \%$-ban fordultak elö (6. ábra).

A felszíni és távérzékelési monitoring adatok rendszerbe történő integrálásával, az úgynevezett intelligens város (Smart City) vezérlése valósulhat meg. Pécs városának tervei között szerepel a Green Capital of Europe pályázat beadása, aminek szerves része lenne egy részletes adatokon alapuló, intelligens mérési és irányítási rendszer üzembe helyezése.

\section{Köszönetnyilvánítás}

A cikket Dr. Lovász György (1931-2016) professzor úr emlékének szenteljük. A szerzők köszönetüket fejezik ki a Tettye Forrásház anyagi támogatásáért és Sárosi Attilának a csapadékmérőhálózat fenntartásáért, valamint az adatok gyüjtéséért. Továbbá köszönet illeti Schmeller Gábort és Horváth Gábort a vízmércék kihelyezésben nyújtott segítségéért.

A szerzők köszönetet mondanak továbbá a lektorok és a szerkesztőbizottság javaslataiért, a tanulmány színvonalasabbá tételében és technikai szerkesztésében nyújtott segítségért.

A jelen tudományos közleményt a szerzők a Pécsi Tudományegyetem alapításának 650. évfordulója emlékének szentelik.

\section{Irodalomjegyzék}

ASCE (American Society of Civil Engineers). (1992). Design and Construction of Urban Stormwater Management Systems. ASCE Manuals and Reports on Engineering Practice No. 77. New York, NY.

Aronica, G. T. \& Candela, A. (2007). Derivation of flood frequency curves in poorly gauged Mediterranean catchments using a simple stochastic hydrological rainfall-runoff model. Journal of Hydrology, 347, 132-142. doi: 10.1016/j.jhydrol.2007.09.011
Bartholy, J., Bozó, L. \& Hapszra, L. (2011). Klimaváltozás - 2011 Klímaszcenáriók a Kárpát-medence térségére. Budapest: A Magyar Tudományos Akadémia és az Eötvös Loránd Tudományegyetem Meteorológiai Tanszéke

Castillo, V. M., Gómez-Plaza, A. \& Martínez-Mena, M. (2003). The role of antecedent soil water content in the runoff response of semiarid catchments. a simulation approach. Journal of Hydrology, 284, 114-130. doi: 10.1016/S0022-1694(03)00264-6

Cobby, D., Falconer, R., Forbes, G., Smyth, P., Widgery, N., Astle, G., Dent, J. \& Golding, B. (2008). Potential warning services for groundwater and pluvial flooding. In Samuels, P., Huntington, S., Allsop, W. \& Harrop, J. (Eds.), Flood Risk Management: Research and Practice (1273-1280). London: Taylor \& Francis Group. doi: 10.1201/9780203883020.ch150

Collier, C. G. (2007). Flash flood forecasting. What are the limits of the predictability? Quarterly Journal of the Royal Meteorological Society, 133, 3-23. doi: 10.1002/qj.29

Corradini, C., Melone, F. \& Smith, R. E. (1997). A unified model for infiltration and redistribution during complex rainfall patterns. Journal of Hydrology, 192, 104-124. doi: 10.1016/S0022-1694(96)03110-1

Cosh, M. H., Jackson, T. J., Bindlish, R. \& Pruegger, J. H. (2004). Watershed scale temporal and spatial stability of soil moisture and its role in validating satellite estimates. Remote Sensing of Environment, 92, 427-435. doi: 10.1016/j.rse.2004.02.016

Czigány, Sz., Pirkhoffer, E., Balassa, B., Bugya, T., Bötkös, T., Gyenizse, P., ... Geresdi, I. (2010). Villámárvíz, mint természeti veszélyforrás a Dél-Dunántúlon. Földrajzi Közlemények, 134(3), 281-298.

EEA (European Environment Agency). (2005). ÉghajlatváltozásésárvizekEurópában.EurópaiKörnyezetvédelmi Ügynökség jelentése. http.//www.eea.europa.eu/hu/publications/briefing_2005_1. Letöltve: 2015. szeptember 12.

Fábián, Sz. Á., Görcs, N. L., Kovács, I. P., Radvánszky, B. \& Varga, G. (2009). Reconstruction of flash flood event in a small catchment. Nagykónyi, Hungary. Zeitschrift für Geomorphologie, 53, 123-138. doi: 10.1127/0372-8854/2009/0053S3-0123

Folmar, N. D., Miller, A. C. \& Woodward, D. E. (2007). History and development of the NRCS lag time equation. Journal of the American Water Resources Association, 43(3), 829-838. doi: 10.1111/j.1752-1688.2007.00066.x

Gaume, E., Bain,V., Bernardara, P., Newinger, O., Barbuc, M., Bateman, A., ... Viglione, A. (2009). A compilation of data on European flash floods. Journal of Hydrology, 367, 70-78. doi: 10.1016/j.jhydrol.2008.12.028 
Georgakakos, K. P. (2006). Analytical results for operational flash flood guidance. Bulletin American Meteorological Society, 317, 81-103. doi: 10.1016/j. jhydrol.2005.05.009

Giandotti, M. (1934). Previsione delle piene e delle magre dei corsi d'acqua. Istituto Poligrafico dello Stato, 8, $107-117$.

Green, J. I. \& Nelson, E. J. (2002). Calculation of time of concentration for hydrologic design and analysis using geographic information system vector objects. Journal of Hydroinformatics, 4(2), 75-81.

Grimaldi, S., Petroselli, A., Tauro, F. \& Porfiri, M. (2012). Time of concentration. a paradox in modern hydrology. Hydrological Sciences Journal, 57(2), 217-226. doi: $10.1080 / 02626667.2011 .644244$

Grundfest, E. (1977). What people did during the Big Thompson Flood. Working Paper No. 32. Natural Hazards Research and Applications Information Center. Boulder, CO

Hegedüs, P., Czigány, Sz., Balatonyi, L. \& Pirkhoffer, E. (2013). Analysis of Soil Boundary Conditions of Flash Floods in a Small Basin in SW Hungary. Central European Journal of Geosciences, 5(1), 97-111. doi: 10.2478/s13533-012-0119-6

Hegedüs, P. (2014). Villámárvizek peremfeltételeinek numerikus modellezése a Mecsek kisvízgyüjtöinek példáján ( $\mathrm{PhD}$ értekezés). Pécsi Tudományegyetem, Földtudományok Doktori Iskola. Elérhető: Pécsi Egyetemi Archívum, http://pea.lib.pte.hu/handle/pea/15032

Hegedüs, P., Czigány, Sz., Pirkhoffer, E., Balatonyi, L. \& Hickey, R. (2015). Analysis of spatial variability of near-surface soil moisture to increase rainfall-runoff modelling accuracy in SW Hungary. Open Geosciences, 7, 126-139. doi: 10.1515/geo-2015-0017

Hinman, C. (2005). Low impact development. Technical guidance manual for Puget Sound. Washington State University. Puget Sound Action Team. Olympia, WA

Horváth, Á. (2005). A 2005. április 18-i mátrakeresztesi árvíz meteorológiai háttere. Légkör, 50(2), 6-10.

Izzard, F. C. (1946). Hydraulics of runoff on developed surfaces. In Proceedings of the Twenty-Sixth Annual Meeting of the Highway Research Board (pp. 129-146). Washington, DC

Javier, J.R.N., Smith, J.A., Meierdiercks, K.L., Baeck, M.L. \& Miller, A.J. (2007). Flash flood forecasting for small urban watersheds in the Baltimore metropolitan region. Weather and Forecasting, 22, 1331-1344. doi: 10.1175/2007WAF2006036.1
Jiang, W. \& Gan, J. (2012). Importance of Fine Particles in Pesticide Runoff from Concrete Surfaces and Its Prediction. Environmental Science \& Technology, 46, 6028-6034. doi: 10.1021/es300749p

Kerby, W. S. (1959). Time of concentration for overland flow. Civil Engineering, 29(3), 174 p.

Kirpich, Z. P. (1940). Time of concentration of small agricultural watersheds. Civil Engineering, 10(6), 362 p.

Klug, H. \& Oana, L. (2015). A multi-purpose weather forecast model for the Mondsee Catchment. Journal for Applied Geoinformatics, 1, 602-611. doi: 10.1553/giscience2015s600

Lóczy, D., Pirkhoffer, E., \& Gyenizse, P. (2012). Geomorphometric floodplain classification in a hill region of Hungary, Geomorphology, 147-148, 61-72. doi: 10.1016/j.geomorph.2011.06.040

Martinez, F., Casermeiro, M.A., Morales, D., Cuevas, G. \& Walter, I. (2003). Effects on run-off water quantity and quality of urban organic wastes applied in a degraded semi-arid ecosystem. The Science of the Total Environment, 305, 13-21. doi: 10.1016/S0048-9697(02)00472-2

Morgali, J. R. \& Linsley, R. K. (1965). Computer analysis of overland flow. Journal of the Hydraulics Division, 91, 81-101.

McCuen, R. H. (2009). Uncertainty analyses of watershed time parameters. Journal of Hydrologic Engineering, 14 (5).490-198. doi: 10.1061/(ASCE)HE.1943$\underline{5584.0000011}$

Pirkhoffer, E., Czigány, Sz., Hegedüs, P., Balatonyi, L., \& Lóczy, D. (2013). Lefolyási viszonyok talajszempontú analízise ultra-kisméretü vízgyüjtőkön. Tájökológiai Lapok, 11(1), 105-123.

Ronczyk, L. \& Wilhelm, Z. (2006). Beneficial use of the stormwater in Pécs. Grazer Schriften der Geographie und Raumforschung, 40, 135-144.

Ronczyk, L. \& Czigány, Sz. (2014). Pécsi hidrológiai tájékoztató 2014, Pécs: Pécsi Tudományegyetem, Földrajzi Intézet

Ronczyk, L., Czigány, Sz., Horváth, M., \& Lóczy, D. (2015). Urban stormwater runoff and pressure on the sewerage system in Pécs, Southwest-Hungary. CSE Journal - City, Safety, Energy, 1, 32-43.

Sarangi, A., Madramootoo, C. A., Enright, P., \& Prasher, S. O. (2007). Evaluation of three unit hydrograph models to predict the surface runoff from a Canadian watershed. Water Resources Management, 21, 1127-1143. doi: 10.1007/s11269-006-9072-9

Stelczer, K. (2000). A vizkészlet-gazdálkodás hidrológiai alapjai. Budapest: ELTE Eötvös Kiadó 
Szlávik, L. \& Sziebert, J. (2006). Hidrológia és Meteorológia. Föiskolai Jegyzet. Baja: Eötvös József Föiskola

Stevaux, J.C. \& Latrubesse, E. (2010). Urban floods in Brazil. In Lautrubesse, E. (Ed.), Geomorphology of natural hazards and human exacerbated disasters in Latin America (pp. 245-266). Amsterdam: Elsevier

Straub, T.D., Melching, C.S., \& Kocher, K.E. (2000). Equations for estimating Clark Unit-Hydrograph parameters for small rural watersheds in Illinois. Water-Resources Investigations Report 00-4184. Urbana, IL: USGS
USACE (US Army Corps of Engineers). (2001). HECHMS hydrologic modeling system, user's manual, version 2.2.1. Vicksburg, MS

Wanielista, M.P., Kersten, R. \& Eaglin, R. (1997). Hydrology: Water Quantity and Quality Control (2nd Edition). New York, NY: Wiley

Yen, B. C. \& Chow, V. T. (1983). Local Design Storm: Volume II. - Methodology and Analysis. Washington, DC Zsuffa, I. (1996). Müszaki Hidrológia I. Budapest: Mủegyetem Kiadó 
